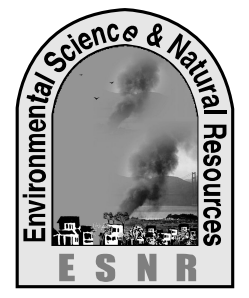

J. Environ. Sci. \& Natural Resources, 5(1): 187 - 191, 2012

ISSN 1999-7361

\title{
Status of Solid Waste Generation at Jahangirnagar University Campus and Development of a Suitable Management Plan
}

\author{
A. H. M. Saadat, F. Parvin, A. T. M. J. Alam and A. K. I. Kamal \\ Department of Environmental Sciences, Jahangirnagar University, Savar, Dhaka
}

\begin{abstract}
Present status of solid waste generation of Jahangirnagar University campus was assessed and its probable utilization was examined and a suitable management option is prescribed. Study includes waste generation in the teachers and staff quarters, central cafeteria and different student's halls. It is found that every day about five metric tons of waste generated from different locations and they are dumped into the open environment and deteriorating the environment. Calculations suggest that $30 \mathrm{~kW} / \mathrm{h}$ electricity along with 300 metric tons of compost can be generated from the organic part of the waste in the campus every year. This electricity can be used for continuous electrification of research laboratories or class rooms. The compost generated from the solid waste, can replace the organic and inorganic manure for gardening in the campus which can save a handsome amount of money from the yearly budget of Jahangirnagar University in this sector.
\end{abstract}

Key words: Compost development, Organic waste, Renewable energy

\section{Introduction}

Solid waste is one of the most visible environmental problems in Bangladesh. Absence of comprehensive waste management initiative is making the situation more wasteful in the recent time. Jahangirnagar University is well known for its beautiful green campus. It's consists of 464 quarters of different categories, 11 students hall, a medical centre, administrative building and 32 departments. More than ten thousand people live in the campus area. However, due to lack of a proper waste management strategy, wastes are found to be scattered in the open environment. The open waste dumping often mixed with animal excreta and contributing to flooding, breeding of insects and rodent vectors and spread of diseases (Suttibak et al., 2005). Sometimes these wastes are dumped directly into the surface water bodies which increase the BOD of surface water body and affect the aquatic community (Mostazi, 2007). This results in degradation of aesthetic and environmental quality of the campus. Moreover it is established that unscientific solid waste management or disposal is contributing to global warming (Lauber, 2005; Taylan et al., 2007 and Allen et al., 1997). So, it has become necessary to manage the solid waste of the campus in a scientific way. For the protection of environmental quality and recreation potential of the Jahangirnagar University campus there must be a specific strategy for the solid waste in the campus.

On the other hand, generation of electricity from solid waste by constructing biogas plant is popular in many countries such as Sweden (Oosterveen, 2008),
Greece (Gruner, 2007), Nepal (Solans, 2007) and Ukraine (Geletukha and Matveev, 2004) etc. Biogas plant from solid waste has three distinct advantages: a) management of waste, $b$ ) production of renewable energy and c) improve management of plant nutrients (Oosterveen, 2008). To solve the electricity problem of the country it has become essential that every institution should partially fulfill their electricity demand from renewable energy. In the present study, status of solid waste management of Jahangirnagar University is assessed and the prospect of compost production and electricity generation from degradable waste is determined.

\section{Methodology}

This research work was done by direct investigation, questionnaire survey, data collection, sample collection and analysis. To analyze the present solid waste management practice and for a proposed plan of waste management the following methodology has been followed.

\section{Collection of data}

Data on present status of waste generation of Jahangirnagar university campus were collected from the central cafeteria and different student's halls by weighting mechanically on the basis of per capita waste generation information. Among teachers and staff quarters 50 residents were randomly selected for questionnaire survey.

\section{Identification of waste generation sites}

Location of waste generation sites was identified by field investigation and using GPS. Map of waste 
generation sites was prepared by using Arc GIS version 9.2.

\section{Results and discussions}

\section{Present status of waste generation}

It was found from the study that every day around $4757 \mathrm{~kg}$ of solid waste (Table 1) generated from different locations and they are dumped to the open environment and deteriorating the aesthetic value of the environment. Maximum wastes are generated from residential units, student hostels and from commercial places. Among these wastes, $75.5 \%$ is organic wastes and $17 \%, 7.1 \%$ and $0.5 \%$ are combustible, non-combustible and hazardous waste (Figure 1) respectively. The organic wastes are mainly food wastes and the inorganic wastes are plastics, glass, tin etc. The hazardous wastes are medical wastes, used sanitary pads etc., but they are in negligible amount compared to other wastes.

Table 1. Amount of solid waste generation in Jahangirnagar University

\begin{tabular}{|c|c|c|c|c|c|}
\hline \multirow{3}{*}{ Sources } & \multicolumn{4}{|c|}{ Volume of waste generated per day (in kg) } & \multirow{3}{*}{$\begin{array}{l}\text { Total } \\
\text { (in } \mathrm{Kg} \text { ) }\end{array}$} \\
\hline & \multirow{2}{*}{ Organic } & \multicolumn{2}{|c|}{ Inorganic } & \multirow{2}{*}{ Hazardous } & \\
\hline & & Combustibles & Non-combustibles & & \\
\hline Residential units & 1655 & 357 & 250 & 2 & 2264 \\
\hline Student hostels & 1534 & 239 & 68 & 17.5 & 1858.5 \\
\hline Administrative offices & - & 16.5 & - & - & 16.5 \\
\hline Academic units & 16.5 & 34.5 & 4.5 & 0.002 & 55.502 \\
\hline Commercial places & 229 & 29 & 5 & 2 & 265 \\
\hline Medical & - & 0.5 & - & 1 & 1.5 \\
\hline Other Common places & 83.5 & 31 & 7 & - & 121.5 \\
\hline $\begin{array}{l}\text { Street sweeping and drain } \\
\text { cleaning }\end{array}$ & 72 & 101 & 2 & - & 175 \\
\hline Total & 3590 & 808.5 & 336.5 & 22.502 & 4757.502 \\
\hline
\end{tabular}

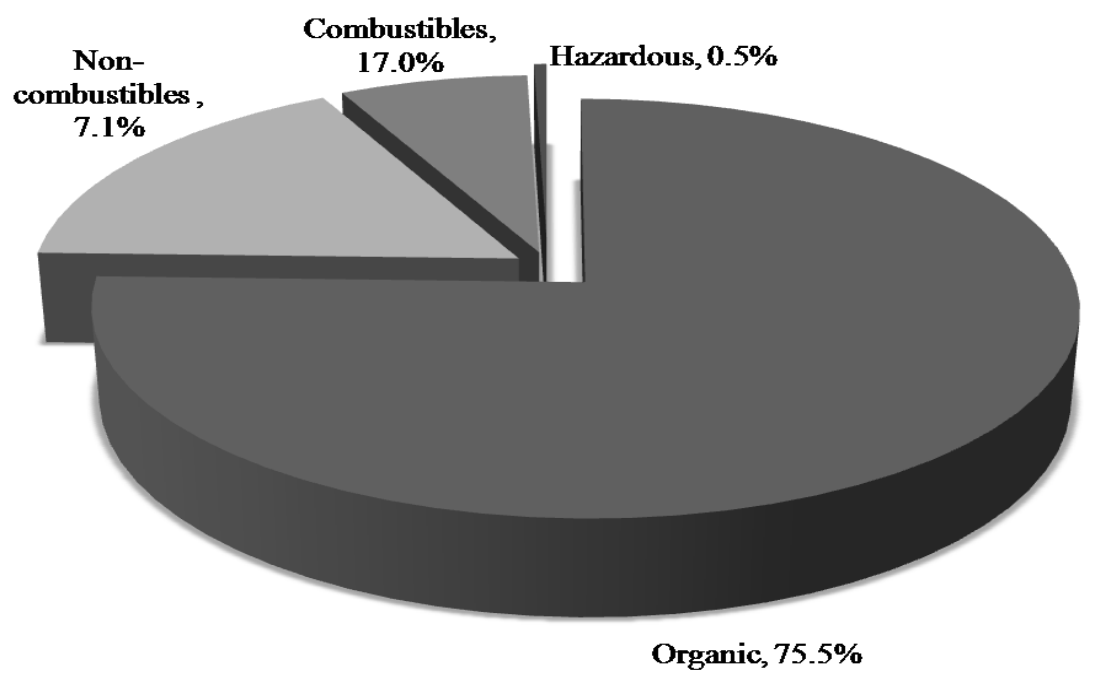

Fig. 1. Composition of solid waste in Jahangirnagar University campus. 


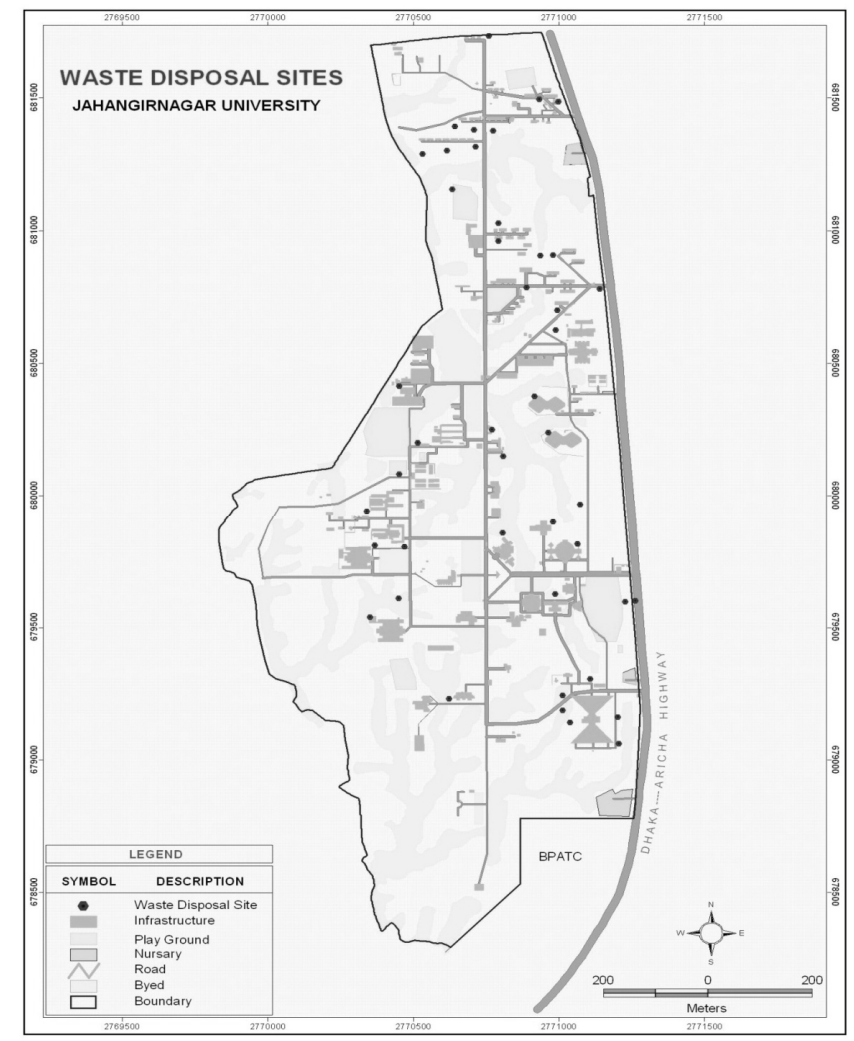

Fig. 2. Waste disposal sites of Jahangirnagar University Campus.

\section{Present status of solid waste management}

There is no solid waste management strategy of Jahangirnagar University campus at present. The location of the solid waste generating point of the campus is shown in figure 2 . In this figure it has shown that about 43 waste dumping sides were found in the campus area. And maximum waste dumping sites are located besides the lakes. The generated wastes not only damages the aesthetic value but also causing different types of diseases to the inhabitants of the campus, as the putrescible organic wastes are mixed with the lake water.

\section{Proposed management plan}

\section{Waste Collection}

The waste collection system may be a combination of communal and house to house collection. The householders should dispose their kitchen waste in the container provided by the project. In the teacher and official community, a waste collection bean would be placed in front of every building. The house holders would dispose their kitchen waste in that bean. In different student halls, waste collection bean would be provided in different kitchens of the halls.

From the waste collection beans, waste would be collected by the collection workers of the project. For waste collection from the waste collection beans in Jahangirnagar university two collection workers are required. Waste would be collected by them and traveled to the disposal site with waste collection rickshaw vans. The accommodation of these workers would be performed by the money, provided by the community for waste collection purpose.

\section{Generation of Electricity}

Many countries of the world meeting their electricity demand from biogas. In the year 2007, USA meets 3 to $6 \%$ of their electricity demand from biogas which used 254.1 million ton of waste (EESI, 2009 and EPA, 2008a). UK estimated that from the 28 million ton of house hold waste $1700 \mathrm{MW}$ electricity can be produce every year which is enough to meet the demand of 2.7 million household (EPA, $2008 \mathrm{~b}$ ).

In the disposal site, the workers would separate the non biodegradable part, such as plastic glass etc. 


\section{J. Environ. Sci. \& Natural Resources, 5(1): 187- 191, 2012}

Then the degradable part would be transferred to the initial degradation chamber of a biogas plant. In the initial degradation chamber the degradable waste are mixed with water to start the initial degradation process. A relevant amount of cow dung might also be mixed with the organic waste to stimulate the process. Here the wastes are kept for three to four days. After that, the waste is transferred to the in late chamber of the $350 \mathrm{cft}$ biogas plant for the generation of biogas.

As illustrated in table I total amount of organic waste that is generated from the Jahangirnagar University is $3590 \mathrm{~kg}$. According to the recommendation of the Deputy Director of Rural Development Academy (RDA), Bogra, Mahmud Hossen Khan (Personal communication) for establishing a $350 \mathrm{cft}$ biogas plant $3590 \mathrm{~kg}$ of organic waste is required. By utilizing the $350 \mathrm{cft}$ gas generated from the biogas plant one can operate three generator of $10 \mathrm{kVA}$. This will generate $30 \mathrm{kw} / \mathrm{h}$ of electricity. So from the $3590 \mathrm{~kg}$ of organic waste $30 \mathrm{kw} / \mathrm{h}$ electricity can be generated. As most of the waste materials are food waste, they have the possibility of containing methane $\left(\mathrm{CH}_{4}\right)$ up to $85 \%$ (Zaigham and Nayyer, 2005). This electricity can be used for different purpose such as continuous supply of electricity in the research laboratory or cooking purpose. Suppose a middle class family is operating two fans, one 21 inch color television, and four rod lights. There electricity consumption is given in the following Table 2.

Table 2. Electricity consumption of a middle class family

\begin{tabular}{l|c|c}
\hline Name of electrical equipment with power & Number & Electricity consumed $(\mathrm{w} / \mathrm{h})$ \\
\hline Tube light of 40 watt & 4 & 160 \\
\hline Fan of 65 watt & 2 & 130 \\
\hline 21 inch television of 80 watt & 1 & 80 \\
\hline \multicolumn{2}{c|}{ Total electricity consumed $(\mathrm{w} / \mathrm{h})$} & 370 \\
\hline
\end{tabular}

The electricity consumption of a middle class family is $370 \mathrm{~W} / \mathrm{h}$. By utilizing $350 \mathrm{cft}$ of gas $30000 \mathrm{~W} / \mathrm{h}$ electricity can be generated that can meet the needs of around 90 middle class families without any load shedding.

\section{Compost Development}

Compost is organic material that can be used as a soil amendment or as a medium to grow plants. Mature compost is a stable material with content called humus that is dark brown or black and has a soil-like, earthy smell. It is created by combining organic wastes (e.g., yard trimmings, food wastes, manures) in proper ratios into piles, rows, or vessels; adding bulking agents (e.g., wood chips) as necessary to accelerate the breakdown of organic materials; and allowing the finished material to fully stabilize and mature through a curing process (Bruijstens et al., 2008). Three types of composting are typical and can produce 0.25 tons of compost from 1.0 tons of organic waste (Enayetullah et al., 1996). These composts are very useful fertilizer. These composts not only increase the productivity but also increase the fertility of the land. The use of the compost fertilizer also reduces the agricultural pollution. After meeting the demand of the university for gardening purpose these composts may also be supplied to the local farmers. The economic viability of compost is given in table 3 .

Table 3. The economic benefits of composting of waste materials

\begin{tabular}{cccc}
\hline $\begin{array}{c}\text { Amount of Organic } \\
\text { Waste (tons/year) }\end{array}$ & $\begin{array}{c}\text { Total Amount of } \\
\text { Compost (ton) }\end{array}$ & $\begin{array}{c}\text { Price per kg of } \\
\text { Compost (TK) }\end{array}$ & $\begin{array}{c}\text { Total price of Compost } \\
\text { (thousand Taka) }\end{array}$ \\
\hline 1310 & 328 & 8 & 2620.00 \\
\hline
\end{tabular}




\section{J. Environ. Sci. \& Natural Resources, 5(1): 187- 191, 2012}

\section{Conclusions}

This database shows that the daily generation of solid waste in Jahangirnagar University campus is about $4757.502 \mathrm{~kg}$ and among which $75.5 \%$ is organic. These organic wastes are house hold waste so there are less chance for hazardous material when it will convert in to the compost. It is possible to generate $30 \mathrm{~kW} / \mathrm{h}$ of electricity and about 300 metric tons of compost. This electricity can meet the demand of at least 90 middle class families of the campus or the different research laboratory can be supported 24 hours of electricity. On the other hand huge amount of cow dung has to buy every year for gardening purpose by the Jahangirnagar University, the compost which will be generated from the solid waste can replace the organic and inorganic manure for gardening in campus and the campus can also earn a handsome amount by selling the extra compost.

\section{References}

Allen, M. R., A. Braithwaite, and C. C. Hills. 1997. Trace organic compounds in landfill gas at seven UK waste disposal sites. Environ. Sci. Technol. 31:1054-1061

Bruijstens, A.J., Beuman, W.P.H., Molen, M.V.D., Rijke, J.d., Cloudt, R.P.M., Kadijk, G., Camp, O.O.D., Bleuanus, S. 2008. Biogas Max, 3.

EESI. 2009, Environmental and Energy Study Institute, $1 \mathrm{p}$.

Enayetullah, I., Sinha, A.H.M. 1996. 'Waste Concern: Concerned with Waste Earth Magazine, October 7.
EPA. 2008a, Environmental Protection Agency. EPA 2008bURL:www.epa.gov/epawaste/nonhaz/muni cipal/pubs/msw07-rpt.pdf, 2008.

Geletukha, G., Matveev, Y., 2004. 2nd World Conference on Biomass for Energy, Industry and CHmale Protection, Rome, Italy May., 10-14.

Gruner, S. 2007. M.S. thesis Roskild University, Greece, 26p.

Lauber, J. D. 2005. Waste to Energy Technology Presents a Viable Solution. In proceedings of the Toronto City Council Municipal Solid Waste Conference: Advances in Processes and Programmes, May 12.

Mostazi, M.A. 2007. BSc Project, Jahangirnagar University. 15p.

Oosterveen 2008 Oosterveen, P. 2008. An explorative study analyzing differences in economical feasibility at large scale biogas plant in Sweden. M.S thesis, Wageningen University, Netherlands, P 15

Solans, C.; Sadurní, N.; Calderó, G.; Azemar, N.; Garcia-Celma, M.J.; Shrestha, L.K.; Aramaki, K. 2007. Nano-emulsions: Formation by LowEnergy Methods and Properties. International Conference on Emerging Issues on Research and Development, April 4-6, 2007, Kathmandu Nepal

Suttibak, S., Nitirattanon, V. 2005. Proceedings of International Conference of Solid Waste Management in South Asian Cities, Creambodia, Thailand, July 5-7. 74p.

Taylan, V., Dahiya, R. P.; Anand, S. and Sreekrishnan. 2007. Quantification of methane emission from solid waste disposal in Delhi. $J$. Resour., Conserv. Recycling, 2007, 3, 240-259.

Zaigham, N. A., Nayyer, Z. A. 2005. In Proceedings of Renewable Energy Technologies \& Sustainable Development, 65p. 